\title{
A Note On The Formal And Informal Sector Economies In Mexico: How Strongly Does Social Network Theory Explain Microentepreneurial Success?
}

José Castillo, Truman State University, USA

Debra K. Cartwright, Truman State University, USA

\begin{abstract}
Previous studies examining the effects of social network theory have largely been conducted in the context of highly industrialized and economically robust countries. In contrast, Mexico is a developing country that has historically experienced extreme poverty, low productivity and significant financial problems. And despite being the $15^{\text {th }}$ largest nation and the $13^{\text {th }}$ largest economy by volume, it is a country where only until recently a sketchy picture of the smallest of entrepreneurs and his/her activities have begun to materialize. This paper outlines an effort to add substance and contrast to this picture, and argues that social network theory may actually depict two vastly different portraits of entrepreneurship in Mexico.
\end{abstract}

\section{INTRODUCTION}

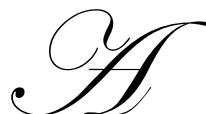

ccording to social network theory, entrepreneurial decision-makers ${ }^{\prime} \ldots$ embed their business decisions in social structures" (Greve and Salaff, 2003, p. 1). That is to say, entrepreneurs rely on the advice of family, friends and professional experts to make important business decisions (Hernandez-Trillo, Pagán, and Paxton, 2005; Renzulli, Aldrich, and Moody, 2000). Recently, Greve and Salaff (2003) supported this finding using a sample of Italian, Norwegian, Swedish, and American enterprises in which they found evidence that "...entrepreneurs in diverse cultural settings access their social relations in similar ways...[and that]...discussion network size and time spent developing and maintaining relations depend on...[the]...phase...[across]...countries"(Greve and Salaff, 2003, p. 17).

Nevertheless, there are vast differences in conditions between the countries studied by Greve and Salaff (2003) that are among the largest in terms of GDP and economic power and a developing nation like Mexico. Even though Mexico is the $15^{\text {th }}$ largest nation and the $13^{\text {th }}$ largest economy by volume, it has suffered from over fifty years of extreme poverty, low productivity and significant financial crises. And while the experts may quibble on the figures, Mexico's economy is made up of upwards of 30\% informal sector employment of which most are individuals unable to keep or land formal sector employment among which are underage, uneducated children (Report VI Decent work and the informal economy, International Labour Conference, 2002).

This paper illustrates the context under which the smallest of business is transacted and advances a model of such entrepreneurship in Mexico. The paper extends the findings of Greve and Salaff's (2003) study into the area of developing economies and posits that Mexican microentrepreneurs use social networks as described in their study. However, we argue that there are mitigating circumstances that make it so that these networks do not bear similar results, and, indeed, may demonstrate that social network theory as applied to developing nations may give somewhat dichotomous results in which social networks may be very fruitful for one type of enterprise, while in other social networks may only apply weakly, and, possibly, not at all. 


\section{BACKGROUND}

\section{Social Network Theory}

Management researchers and practitioners have been interested in the effects of social networks since Granovetter's (1973) seminal piece, and recently the topic has been featured in special issues of some of the top management journals (e.g., Academy of Management Journal, 2004, Vol. 47 Issue 6; Academy of Management Review, 2005, Vol. 31 Issue 3; Entrepreneurship Theory and Practice, 2006, Vol. 30 Issue 2; Asia Pacific Journal of Management, 2005, Vol. 22 Issue 4). Speaking to this popularity, Borgatti and Foster (2003) comment on the increasing number of publications focusing on social networks since 1970 and categorize these works with articles regarding "social capital," which demonstrates the overall "value of connections." They claim that these connections may be as measurable as, but much more valuable than, liquid assets. "Embeddedness" is another category in Borgatti and Foster's (2003) typology. These studies examine economic transactions between subjects and claim that these interactions occur within the context of broader social and economic conditions. Therefore, one can conclude from Greve and Salaff's (2003) study that entrepreneurs both provide and utilize "social capital" to maximize the effectiveness of their endeavors. And interactions strengthened by this capital attain increasing degrees of success depending on the depth of the transaction's "embeddedness" in addition to the phase of the business. We posit an ideal example might be an entrepreneur who has attained the smoothest of supply chain management to his or her operation. It would not seem unreasonable to suppose that such an entrepreneur achieved this by mining deeply for, and using "social capital" far up and down the chain of suppliers, and possibly even customers.

\section{Mexican Economic Picture}

According to the CIA World Factbook (2009) the economies examined in Greve and Salaff's (2003) study, namely, Norway, United State, Sweden and Italy, rank $7^{\text {th }}, 10^{\text {th }}, 23^{\text {rd }}$, and $43^{\text {rd }}$ in per capita GDP, while Mexican entrepreneurship takes place in the context of an economy that ranks $82^{\text {nd }}$ in per capita GDP, and, by comparison, in rather other-worldly conditions(www.cia.gov). Strong economies achieve and sustain their strength through a welldeveloped infrastructure designed to accommodate and overcome human and environmental conditions. By such a standard Mexico's infrastructure is underdeveloped to be sure. The country is working hard to build an enduring and stable representative government, successful educational and financial institutions, and effective communication and transportation networks. A complete discussion of these factors is beyond the scope of this paper (see Brookings Papers on Economic Activity, 2003) however, additional attention to the country's education system may be helpful.

Based on the extensive literature regarding absorptive capacity, learning curves and knowledge transfer technological innovations are most likely to occur when institutions of higher learning and industry work cooperatively (Child and McGrath, 2001). However, only a handful of Mexican universities (the Autonomous University of Mexico system and the Monterrey Technological Institute system) would be classified as Research I caliber schools by the Carnegie Classification of Institutions of higher education standards and only a few state-ofthe-art research lab facilities have been equipped. In addition, faculty research has only recently been added to the missions of public universities and built into their reward systems (i.e., PRONEP at http://promep.sep.gov.mx/ is the government agency in Mexico that tracks research productivity for individual university professors). Therefore, it is reasonable to conclude that the current infrastructure has not been sufficient to support either the same quality of technological innovations or the quantity of entrepreneurs willing to risk their family's future as is supported in more advanced countries such as the United States or Norway for example.

In comparison to the more developed economies used in Greve and Salaff's (2003) study, Mexican industry is struggling with the consequences of the industrialization process in developing nations. As countries adapt from an agrarian economy to a more industrialized economy, its citizens migrate from rural areas to the cities in search of employment opportunities. The end result of this migration is "...rapid urban growth and...the rise in cities of an excess labor supply relative to labor demand" (Portes and Schauffler, 1993, p. 38). The Organization for Economic Co-operation and Development (OECD) provides a rather negative portrayal of economic conditions in Mexico saying that economic growth ".... is constrained by low levels of human capital, while additional fiscal resources are 
needed to improve and expand inadequate physical infrastructure, and combat widespread acute poverty that lead to poor health and social marginalization...[in addition to]...blunted incentives for the private sector to invest and innovate" (OECD Policy Brief: Economic Survey of Mexico, 2003, p. 2). Supporting this assessment, the USAID estimates that approximately 50 million live below the poverty line, and $42 \%$ of these rural households live in "extreme poverty" (USAID, 2005).

While this economic environment presents definite challenges, Mexican businesses also face a government rife with graft and bureaucratic red tape, a communication system that is improving, but still inadequate even after years of deregulation, and a financial services system with little individual savings to fund the development and growth of entrepreneurial businesses. Under these adverse conditions how likely is it that social networks will lead to greater entrepreneurial success? Or, is it more likely that the opposite will be true?

\section{Entrepreneurship in Mexico}

Given such a business setting, what has been the result for entrepreneurial activity in Mexico? The answer is that Mexico's economy is one of the most highly segmented economies between the formal and informal sectors in Latin America, with estimates ranging between 22\% to 30\% informal economy. Meaning that, rather than a thriving entrepreneurial spirit spurned on by previous successes stimulated by growth and profit motives that are aided by, and in harmony with governmental agencies, entrepreneurship in many cases can be characterized as a multitude of "...small-scale, semi-legal, often low-productivity, frequently family-based, perhaps pre-capitalistic enterprise[s]" (Maloney, 2004, p. 1159). And so the enduring question is, "... whether a thriving informal sector is a sign of a healthy economy where citizens at all levels willingly and ably participate in the informal sector in pursuit of their entrepreneurial dreams...[or, is it a sign that]...large percentages of...[the]...population...[are sadly stuck] ...unable to find employment outside informal sector occupations"? (Castillo, 1997, p. 22).

The 2002 National Survey of Microenterprises (Encuesta Nacional de Mocrodegocios, ENAMIN) reports that nearly 4.5 million microenterprises operate in its large urban areas of 100,000 inhabitants and above. Conservatively estimating that half of Mexico's population lives in locals of less than 100,000, this would mean that there are nearly nine (9) million microenterprises in Mexico (to participate in the ENAMIN survey a business cannot have more than six workers including the owner, and must conduct business from a physical permanent location). Adding to this figure another conservative 4.5 million microentrepreneurs that are not captured in the survey because they are ambulatory businesses with no fixed base of operation, the figure quickly jumps to approximately 13.5 million microenterprises operating in the formal and informal sectors. According to Hernandez-Trillo et al. (2005) "...only about two fifths of microenterprises operate in the formal sector in the sense that they are registered... with Mexico's fiscal authority" (p. 439). By this definition, it is possible to conclude that upwards of 8 million microenterprises may possibly operate unhindered by government regulations and pay no taxes, but at the same time receive no critical business-sustaining benefits as a result. Thus it is that a rather sizable portion of Mexico's entrepreneurs possess no more than a high school education, have no access to governmental agencies established to help business owners secure and pay loans, and, have little counsel from private organizations established to promote small (registered) businesses.

In looking at this condition from the perspective of social networks, informal sector entrepreneurs must have significantly reduced networks of contacts compared to their formal sector counterparts. And this, by all accounts, should mean that success along any number of measures should come to formal sector entrepreneurs far more frequently than to those who operate informal sector enterprises. On these premises we offer the following conceptual model.

\section{CONCEPTUAL MODEL}

The broader management literature is replete with evidence of the artifacts of financial success and growth of an enterprise and a complete list could be quite exhaustive. However, from the entrepreneurship and small business management literature, we focus on a few arguments from which it is possible to advance the following ten (10) propositions. 
A fundamental idea in finance is that the amount of financial leverage is a measure of the risk propensity of the business owner(s); that is, risk taking owners are more likely to take on debt for the potential benefits that may accrue versus risk averse business owners. And perhaps this risk propensity is dependent on the extant conditions of the business (i.e., formal versus informal operations), where registered businesses with access to their larger-sized networks would feel freer to attempt to maximize wealth by leveraging their positions with debt, while informal business owners, due in part to their transitory nature would choose zero debt, perhaps because of the perception that a payment obligation every month represents a risk they wish to avoid. Thus, we make the following proposition:

Proposition 1: The debt structure will be higher for registered firms operating in the formal sector economy than their informal sector counterparts.

Wakefield and Sebora (2004) ascertained a positive correlation between the number of family members working in a family business and factors correlated to business performance. Specifically, in families with harmonious relationships between actors, conflict over management, vision, ownership, and money is diminished, and thus the families' focus can be on the profitability of the business (Wakefield and Sebora, 2004). It follows that registered family businesses with access to greater numbers of connections are able to easily seek the aid and counsel of important advisors when such matters become problematic. Thus, we offer the following proposition:

Proposition 2a: For family run enterprises, the number of family members employed in the business will be higher for registered firms operating in the formal sector economy than their informal sector counterparts.

Corollary to this is the idea that such family run firms that are harmonious and focused on financial performance are, by default, growing in volume and growing in size. Thus, we make the following corollary proposition:

Proposition 2b: The number of non-family employees gainfully employed in the business will be higher for registered firms operating in the formal sector economy than their informal sector counterparts.

Hernandez-Trillo et al. (2005) argued that firms that utilize traditional sources of funding (e.g., bank loans, credit, etc.) are likely to be more efficient (e.g., highest output for lower or streamlined inputs) than firms that utilize family and friends for such funding. And they found this to be true for start-up microenterprises. We argue that this may be due to the fact that firms operating outside of the mainstream in the informal sector represent far more risk than what bankers and creditors are willing to contend with. Thus, the following proposition is made:

Proposition 3a: The initial start-up capital will have been higher for registered firms operating in the formal sector economy than their informal sector counterparts.

A corollary proposition is to argue that once a registered firm has cultivated his or her networks for the initial startup funding from traditional sources, such an entrepreneur is likely to have higher success in acquiring additional operating funds at any other phase of the business' lifespan. A supporting argument can be inferred in Ahlstrom and Bruton (2006) who propose that in emerging economies like Mexico "...institutional stability is largely unknown" thus banks may be limited in their support of small businesses, and, consequently, the void in such funding is filled by savvy venture capitalists, who themselves are well networked (p. 300). It would seem that in Mexico, while informal and formal sector microenterprises may resort to venture capitalists for funding, there may be a tendency for more firms operating in the fringes to rely heavily on non-traditional sources of funding. Thus, the following corollary proposition is made:

Proposition 3b: Success in acquiring traditional source funds will be higher for registered firms operating in the formal sector economy than their informal sector counterparts.

A well known caveat to the most nascent of entrepreneurs in our schools is that small business failure rates are either caused or exacerbated by being underfunded (Longenecker, Moore and Petty, 2006). And it would seem that informal sector microentrepreneurs should be the ones most testing that caveat, and thus experience higher and quicker failure rates. While on the other hand, one should expect that microenterprises that have been more 
successful in acquiring start-up and operating capital from traditional sources should be more successful and thus be in operation longer. Therefore we make the following corollary proposition:

Proposition 3c: Registered firms operating in the formal sector economy will have been in operation longer than their informal sector counterparts.

Hernandez-Trillo et al. (2005) found that the number of years in business was correlated with success in attaining traditional style funding at start-up of Mexican microenterprises. It is not inconceivable to suppose that this relationship is connected to the age of the business owner and his or her ability to capitalize on their "social capital" in their larger formal sector networks. Thus, the following proposition is made:

Proposition 4: The owner's age will be higher for registered firms operating in the formal sector economy than their informal sector counterparts.

Liao and Welsch (2005) argue that for firms competing in knowledge intensive industries “...access to external knowledge, information, and learning is critical... [compared to]...nontechnology based ventures, which largely focus on access to relatively static external resources" (p. 351). It would seem that technological firms that have higher numbers of connections should be more successful than such firms operating in the informal sector. Thus the following proposition is made:

Proposition 5a: The number of technical service firms will be higher for registered firms operating in the formal sector economy than their informal sector counterparts.

Corollary to this idea is the argument that persons operating technical firms are predisposed to conceptualizing, abstracting, and rationally solving the problems they face more so than their non-technical counterparts. By Hayek's (1952) thinking this might seem counterintuitive given that he saw "engineering" solutions to economic and business problems as flawed, but perhaps time and far more complex conditions and knowledge on how to operate in these may yet prove our thesis to be correct. Thus the following proposition is made:

Proposition 5b: Registered firms operating in the formal sector economy will have higher numbers of business owners with technical backgrounds

Research shows that there is a difference in the way male owners and female owners both view and run their organizations (Singh, Hills, Hybels, and Lumpkin, 1999, Butner and Moore, 1997; Gilligan, 1982; Kamau, McLean and Ardishvili, 1998). Male owners tend to be more competitive, have larger networks, and want to "keep score." Female owners, on the other hand, are more nurturing and supportive in the work environment (Butner and Moore, 1997). Thus, in a more competitive environment where access to support and advice is minimal as in informal sector operations, one would expect that males should dominate. Therefore, the following proposition is made:

Proposition 6: The number of male owned businesses versus female owned businesses will be more evenly distributed for registered firms operating in the formal sector economy than their informal sector counterparts.

It is conceivable that the proposed model could be testable utilizing the latest 2002 version of the National Survey of Microenterprises (ENAMIN) utilizing any number of multivariate techniques. Moreover, following Greve and Salaff's (2002) cross-cultural effort, the test could be conducted in countries high in the per capita GDP rankings and those at the bottom of the rankings, thus in a way ascertaining that regardless of economic conditions, entrepreneurship at the fringes is truly unprofitable and fleeting.

\section{IMPLICATIONS FOR FUTURE RESEARCH}

Given the argument that the picture of entrepreneurship differs vastly depending on the strength of the economy (and, therefore, the institutions) that support it, there are a number of potential avenues for worthy exploration. As INEGI (Mexico's National Institute for Demographic and Economic Statistics) has conducted the National Survey of Microenterprises since 1988, it may be possible to use time series techniques to determine 
whether diminished numbers of connections for informal sector microenterprises has tended to result in basically static positions for these businesses versus the positions of formal sector microenterprises. Here again, validating the argument that informal sector entrepreneurship does not pay. In addition, it could prove instructive to assess the characteristics of the venture capitalist networks Ahlstrom and Bruton (2006) argue operate in countries like Mexico and the networks of those entrepreneurs that they are able to fund - might there be cross-mining and use of "social capital" at the nexus of these networks?

\section{CONCLUSION}

This paper argues that Greve and Salaff's (2003) study of the effectiveness of social networks for support and counsel that leads to initial and long term success of entrepreneurial ventures in Norway, the United States , Sweden, and Italy seems to suffer a serious shortcoming in "generalizability" to entrepreneurship in developing nations. Surely, the foundations on which entrepreneurial pursuits rest must differ vastly between the $5^{\text {th }}, 6^{\text {th }}, 27^{\text {th }}$ and $28^{\text {th }}$ ranked economies in per capita GDP, respectively, and, say, countries in the middle and bottom of the rankings where Mexico as the $87^{\text {th }}$ ranked GDP stands? Perhaps these differences make it so that social networks in Mexico are smaller, less powerful or knowledgeable, and, therefore, less effective in countries with uncharacteristic economic struggles. Thus, this paper posits that explaining entrepreneurial success in developing nations utilizing social network theory may give varying results. Mexico, with its large informal sector economy may represent an excellent test case in some future study for the argument that social network theory applies differently depending on the type of organization in question. Ten propositions are advanced that constitute a model of entrepreneurial success as a result of network contacts and a possible test for future research is advanced.

\section{REFERENCES}

1. Ahlstrom, D. \& Bruton, G. D. (2006). Venture capital in emerging economies: Networks and institutional change. Entrepreneurship Theory and Practice, 30(2): 299-320.

2. Anonymous (2003). Liberalization, growth, and financial crisis: Lessons from Mexico and the world/comments and discussion. Brookings Papers on Economic Activity, Washington, D.C.

3. Borgatti, S. P. \& Foster, P. C. (2003). The network paradigm in organizational research: A review and typology. Journal of Management, 29(6): 991-1013.

4. Butner, E.H. \& Moore D.P. (1997). Women's organizational exodus to entrepreneurship: Self-reported motivations and correlates with success, Journal of Small Business Management 35, 34-46.

5. Castillo, J. \& Wakefield, M. (2007) An exploration of firm performance factors in family businesses: Do families value only the bottom line? Journal of Small Business Strategy, 17(2): 37-51.

6. Castillo, J. (1997). Fertility and informal employment: a study into the economic determinants of birthrates in Mexico. SOCIOTAM: International Journal of Social Sciences \& Humanities, 7(2): 7-33.

7. Child, J. \& McGrath, R. G. (2001). Organizations unfettered: Organizational form in an information intensive economy. Academy of Management Journal, 44(6): 1135-1149.

8. $\quad$ CIA (2009). The World Factbook. Updated August, 2009. <<http://www.cia.gov/cia/publications/factbook/rankorder/2004rank.html >>

9. Gilligan, C (1982). In a different voice: psychological theory and women's development. Harvard University Press, Cambridge, MA

10. Greve, A. \& Salaff, J. W. (2003). Social networks and entrepreneurship. Entrepreneurship Theory \& Practice, 28(1): 1-23.

11. Granovetter, M. (1973). The strength of weak ties. American Journal of Sociology, 78(6): 1360-1380.

12. Hernández-Trillo, F., Pagán, J. A. \& Pastón, J. (2005). Start-up capital, microenterprises and technical efficiency in México. Review of Development Economics, 9(3): 434-447.

13. Hayek, F. A. (1952). The Counter Revolution of Science. Glencoe, Ill: Free Press.

14. International Labour Office (2002). Report VI Decent work and the informal economy. <<http://www.gdrc.org/informal/ILO\%20Inf.\%20Ec.\%20Report\%20VI_ang.pdf 〉>. Geneva, Switzerland.

15. Kamau, D. G., McLean, G. N. \& Ardishvili, A. (1999) Perceptions of business growth by women entrepreneurs, in Frontiers of Entrepreneurship Research, ed. P. Reynolds (et al) Babson College, Babson Park, MA 
16. Liao, J \& Welsch, H. (2005). Roles of Social Capital in Venture Creation: Key Dimensions and Research Implications. Journal of Small Business Management, 43(4): 345-362.

17. Longenecker, J., Moore, C. W., \& Petty, J. W. (2006). Small Business Management: An Entrepreneurial Emphasis. Mason, OH: Thomson/South-Western.

18. Maloney, W. F. (2004). Informality revisited. World Development, 32(7): 1159-1178.

19. OECD (2003, November) Policy brief economic survey of Mexico, 2003. OECD Observer, $\langle<$ www.oecd.org/publications/Pol_brief $\rangle>$

20. Portes, A. \& Schauffler, R. (1993). Competing perspectives on the Latin American informal sector. Population and Development Review, 19(1): 33-60.

21. Renzulli, L. A., Aldrich, H. \& Moody, J. (2000). Family matters: Gender, networks, and entrepreneurial outcomes. Social Forces, 79(2): 523-546.

22. USAID (2005, January) Implementation of the USAID/Mexico microenterprise strategy final report. United States Agency for International Development, Washington, D.C.

23. Singh, R. P., Hills, G. E., Hybels, R. C., \& Lumpkin, G. T. (1999). Opportunity Recognition Through Social Network Characteristics of Entrepreneurs" in Frontiers of Entrepreneurship Research, ed. P. Reynolds (et al) Babson College, Babson Park, MA

24. Wakefield, M.W. \& Sebora, T.C. (2004). An examination of antecedents of conflict over money, management, vision, and control in family businesses. Journal of Business and Entrepreneurship. 16(2) 91-114. 


\section{NOTES}

